\title{
Collecting Landraces of Vegetable Crop Species in the South-West Romania
}

\author{
Sarli Giulio ${ }^{1}$, Tigan Eugenia ${ }^{2}$, Bitonte Domenico ${ }^{1}$, Montemurro Francesco ${ }^{1}$, Montesano Vincenzo ${ }^{1}$, Laghetti \\ Gaetano $^{1}$ and Hammer Karl ${ }^{1}$ \\ 1. Institute of Biosciences and BioResources, National Research Council (IBBR-CNR), Bari 70126, Italy \\ 2. Faculty of Food Engineering, Tourism and Environmental Protection, University “Aurel Vlaicu” of Arad, Arad 310130, Romania
}

\begin{abstract}
A collecting mission was carried out in south-west Romania in October 2013 with the aims: (1) to collect autochthonous crop genetic resources which still present in the south-west of Romania; (2) to assess the presence of on farm of plant genetic resources; (3) to determine the species and the amount of genetic diversity still cultivated and (4) to obtain information from germplasm owners to be used to evaluate the feasibility of an on farm conservation program. Out of 24 explored towns, in 8 , landraces were grown and in all, instances seeds could be obtained. Fifty-three accessions from different crop species were collected in 17 sites, belonging to 10 botanical families, of which solanaceae was the most represented (32\%), followed by fabaceae (17\%), cucurbitaceae (11\%) and alliaceae and brassicaceae (9\%). As expected, vegetable crops were the most collected, reaching a value as $58.5 \%$, spices $20.8 \%$, while pulses $15.1 \%$ and cereals $5.7 \%$ of the total. This collecting mission showed that in internal areas of Romania, germplasm of old landraces of many vegetable and crop species still survive, and indicated the urgency to continue also in other agricultural districts of Romania.
\end{abstract}

Key words: Germplasm collecting, landraces, on farm conservation, Romania.

\section{Introduction}

In the last 10,000 years of the agricultural era of human evolution, a diversification of the plants used by humans has taken place. While hunter-gatherers and farmers relied on well-environmentally adapted local plants, simultaneously, a great migration of farming societies took place from centers of domestication to other regions of the world, expanding both the range of plants at their disposal and the adaptation of these crops to the highly diversified growing environments, thus generating the landraces [1-3].

Since the first plant hunting expedition - carried out on the orders of Queen Hatshepsut during the 18th dynasty of ancient Egypt, the acquisition of new plant resources continued actively over the next millennia, so that exploration and introduction were instrumental in establishing a worldwide diverse agriculture,

Corresponding author: Montesano Vincenzo, Ph.D., research fields: agrobiodiversity collection and management. contributing to the development of the pharmaceutical, dye and horticultural industries all over the world [4-6].

On the other hand, since 20th century, an overall dramatic reduction in infra-specific diversity and a concentration of human activities on a more limited number of crop plants were observed and scientists such as Harlan, J. R. et al. [7-12] expressed concern about the disappearance of genetic diversity, particularly landraces and their substitution by a genetically narrow subset of improved cultivars. Since the study of Vavilov, N. I. [13] on the origin and geography of cultivated plants, germplasm collectors roamed the world to collect this endangered germplasm and preserve it. Also, traditional knowledge associated with biodiversity is considered to be a resource to be preserved, being threatened by cultural extinction $[14,15]$.

Landrace is an important germplasm to move towards sustainable agricultural development also in 
increasing economic development countries of eastern Europe, such as Romania.

In this country, many centuries of agriculture have shaped important traditional agro-ecosystems that constitutes significant in situ repositories of crop genetic diversity. A core subset of agricultural ecosystems is represented by landraces providing the rural communities with food and some income [16]. A recent study shows that Romania represents an important reservoir or genetic pool of landraces in the main crops, particularly in Phaseolus vulgaris L., and either farms or home gardens contribute to the country's agro-biodiversity conservation [16]. In Romania, many farmers are involved de facto in on farm conservation of local populations of cereals, grain legumes, vegetables, industrial and technical crops, spices and medicinal plants [17]. Romania still has a rich genetic diversity of cultivated plants, but it is in danger of extinction if there has no measures towards its conservation. The most important causes are the advanced age of seed producers $(71 \%$ of them are over 60 years old) and the recession of vegetable cultivated areas [18].

In the past, collecting missions of landraces of different crops have been organized Zea mays L., Triticum aestivum L., Hordeum vulgare L., Helianthus annuus L., Secale cereale L., fruit trees, Vitis vinifera L. and forest trees [19-33]. An early summary is provided by Cristea, M. [34].

Romania has a surface of $238.39 \mathrm{~km}^{2}$, out of which, from the administrative point of view, $214.55 \mathrm{~km}^{2}$ or almost $90 \%$ are represented by rural areas [35]. Agriculture has encountered a continuous regress after 1990. The main asset of the country is the agricultural land which was badly managed within last decades. It accounts $61.8 \%$ of country surface, 14.7 million hectares of which the farming land represents 9.4 million hectares $(64.05 \%), 6.74$ million hectares of woods $(26.07 \%), 0.84$ million hectares of paddles and lakes $(3.53 \%)$ and 1.51 million hectares of other surfaces $(6.35 \%)$, respectively [36]. The agricultural land has a surface of $14,836,585$ ha and its structure consists of arable land $62 \%$, pastures $24 \%$, hayfields $10 \%$, vineyards $2 \%$ and orchards $2 \%$ [35]. The most extended arable areas are located in the southern and western plains of the country, while the highlands are dominated by pastures and natural hayfields. Vineyards and orchards are mostly located in the hilly areas of the sub-Carpathians and the Transylvania depression [37].

Romania's climate is not uniform but there are outstanding issues from one region to another. The largest quantities of precipitation fall in mountain areas $(1,200-1,400 \mathrm{~mm})$, as the altitude decreases, the amount of precipitation reduced to $700 \mathrm{~mm}$ isohyets surrounding high mountains and hills in their vicinity [38].

In Romania, the soil is classified according to "Romanian System of Soil Taxonomy". As stated by this classification, above $25 \%$ is represented to "Chernozems" and "Phaeozems" [38]. Chernozem occupies the southern sector of the plain and the interfluvial mountainous agglomerates are characterized by good fertility (fertile to middle fertile), generally negligible surface erosion, locally affected by landslides, medium porous and with heavy texture [39].

In the light of the topics above discussed, it can be stated that: (1) Romania, the south-western part in particular, is an important centre for plant crop genetic resources; (2) the process of genetic erosion also affect this germplasm and (3) garden crops have a good chance for on farm conservation, and it is still possible to find a good amount of biological diversity.

As Szabó, A. T. [40] pointed out: “... the "multicultural" Romania is a "small scale Europe" in itself. "The central part of Romania" was, and still is a "cultural ecotone" between eastern and western Christianity. It is a kind of experimental field for the short term and long-term effects of the European des/integration on the traditional knowledge and associated cultivated plants.”. 


\section{Objective of the Study}

A collecting mission was carried out in south-west Romania in October 2013 within the framework of a European cooperation project "Biodiversity of Species with High Nutraceutical and Agro-energetic Value (AGRO.BIO.)", financed by Basilicata region, OP FEASR 2007-2013, to CNR_-Institute of Bioscience and Bio-resources (IBBR-CNR) in collaboration with University "Aurel Vlaicu” of Arad, Faculty of Food Engineering, Tourism and Environmental Protection of Romania.

The aims of the mission were (1) to collect autochthonous crop genetic resources which still present in the south-west of Romania; (2) to assess the presence of on farm of plant genetic resources; (3) to determine the species and the amount of genetic diversity still cultivated; (4) to obtain information from germplasm owners to be used to evaluate the feasibility of on farm conservation program and (5) to exchange technical knowledge and adoption of common protocols related to germplasm management at risk of extinction between IBBR-CNR and University “Aurel Vlaicu” of Arad-Romania.

\section{Methods}

The collecting mission took place from 13th to 19th October 2013. At each selected site (Fig. 1), where farmers donated a seed sample, passport data were recorded (altitude, longitude, latitude, local name of the site, soil texture and purpose of cultivation). Farmers were interviewed to obtain information about their life (age, family structure and work), about their farm (crops grown and management, etc.), about the landraces (local name, adaptive, agronomic and qualitative traits, etc.) and information related to the use, traditions and social context of the species and on the purpose of the conservation. GPS coordinates were acquired by means of a Garmin GPS map 60CSx.

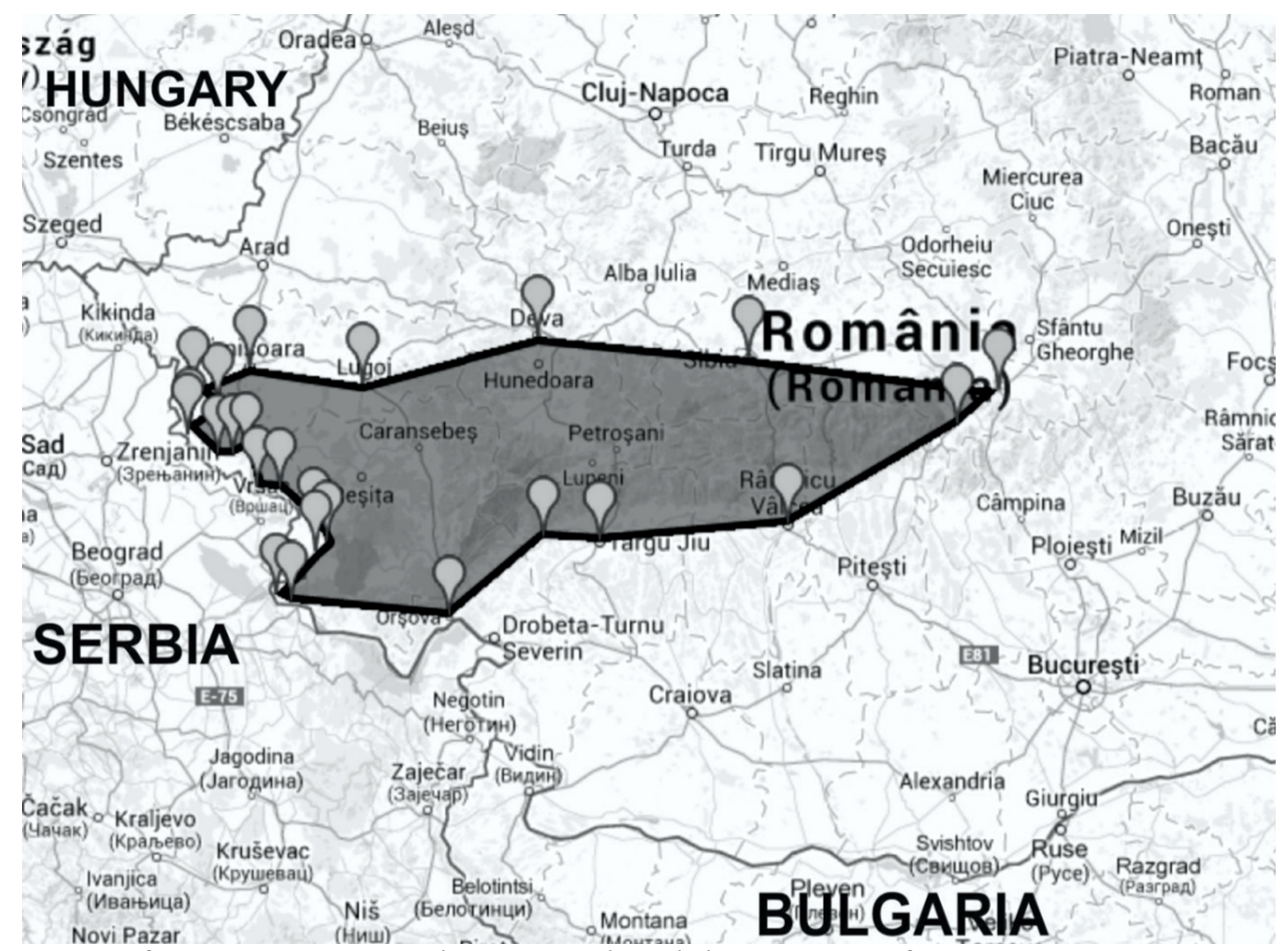

Fig. 1 Roadway of the explored towns during the collecting mission, the names of the explored towns are reported in the below Table 1. 
Species identification, the nomenclature and all the scientific names of the collected plants were updated and confirmed through tropicos database [41].

Back at base, each collected accession was subjected to standard conservation procedures: seeds were cleaned and vacuum sealed in packets and stored in a cold room at $+4{ }^{\circ} \mathrm{C}[42]$.

\section{Results}

Out of 24 explored towns, only in 8 , landraces were grown and in all, instances seeds could be obtained (Table 1).

Fifty-three accessions from different crop species were collected in 17 sites, belonging to 10 botanical families, of which, solanaceae was the most represented (32\%), followed by fabaceae (17\%), cucurbitaceae $(11 \%)$ and alliaceae and brassicaceae (9\%), others are shown in Fig. 2.

In Peciu Nou, the largest number of accessions was collected. In three explored sites, 17 accessions belonging to nine species were found. In Foeni, despite seven sites were visited, only 15 accessions were collected, but belonging to 10 species. In the other visited towns, sites ranged between one and two, with 1 accessions to 7 accessions and 1 species to 5 species (Table 1).

Table 1 Explored districts of south-west Romania and number of collected accessions and species.

\begin{tabular}{lllc}
\hline Town & Number of explored sites & Number of accessions & Number of species \\
\hline Peciu Nou & 3 & 17 & 9 \\
Foeni & 7 & 15 & 10 \\
Arad & 1 & 4 & 4 \\
Lugoj & 1 & 7 & 5 \\
Bran & 1 & 2 & 2 \\
Danubio river & 2 & 5 & 4 \\
Divici & 1 & 2 & 2 \\
Timisoara & 1 & 1 & 1 \\
\hline
\end{tabular}

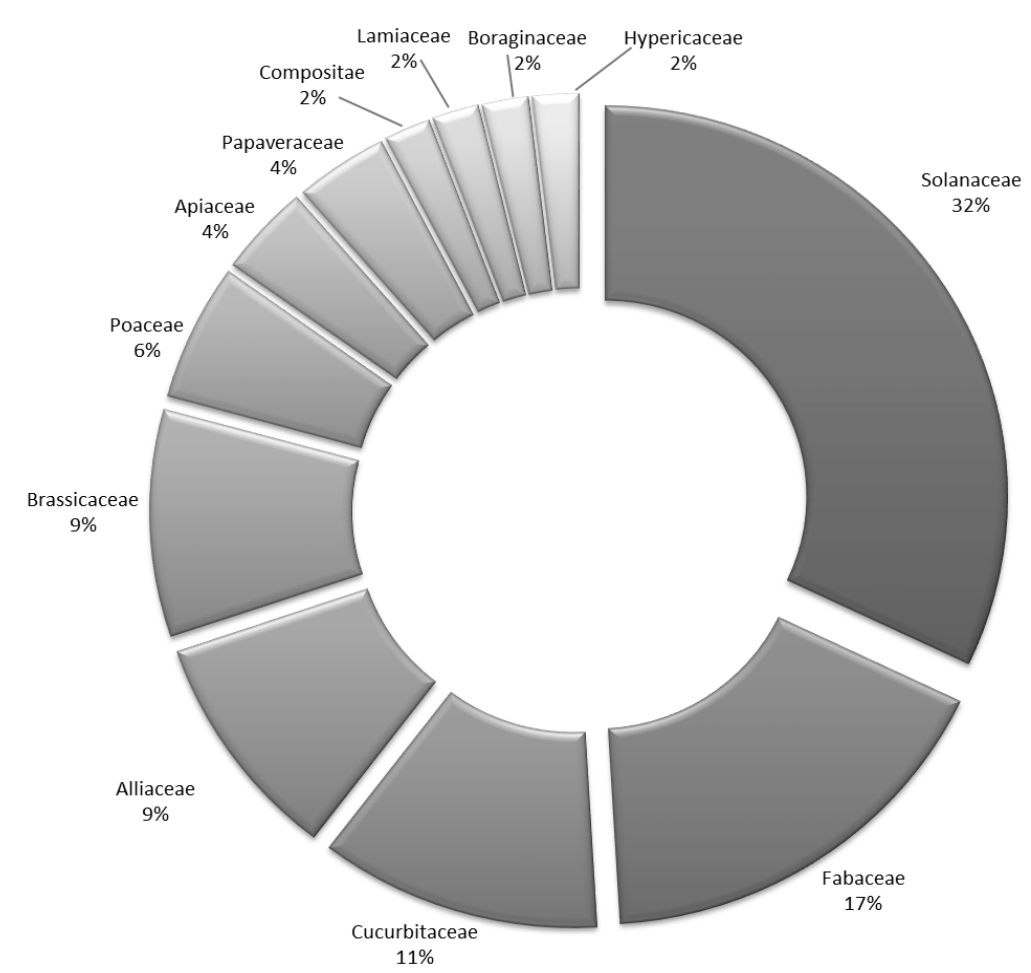

Fig. 2 Botanical families to which belong the 53 accessions of species collected on farm in the south-west Romania. 
Table 2 Number of the collected accessions (grouped in classes) found in the territory of 8 districts in inland areas of south-west Romania.

\begin{tabular}{|c|c|c|c|}
\hline Common name & Crop & Classes & Accessions (n) \\
\hline Tomato & Solanum lycopersicum L. & $\mathrm{vc}$ & 14 \\
\hline Common bean & Phaseolus vulgaris L. & $\mathrm{p}$ & 6 \\
\hline Onion & Allium cepa $\mathrm{L}$. & $\mathrm{vc}$ & 4 \\
\hline Pepper & Capsicum annuиm $\mathrm{L}$. & $\mathrm{vc}$ & 3 \\
\hline Horseradish & Armoracia rusticana G. Gaertn., B. Mey. and Scherb. & $\mathrm{s}$ & 3 \\
\hline Cucumber & Cucumis sativus L. & $\mathrm{vc}$ & 2 \\
\hline Parsley & Petroselinum crispum (Mill.) Fuss. var. tuberosum (Bernh.) Mart. Crov. & $\mathrm{s}$ & 2 \\
\hline Zucchini & Cucurbita pepo L. & $\mathrm{vc}$ & 2 \\
\hline Opium poppy & Papaver somniferum $\mathrm{L}$. & $\mathrm{s}$ & 2 \\
\hline Garlic & Allium sativum L. & $\mathrm{vc}$ & 1 \\
\hline Yard-long bean & Vigna unguiculata subsp. sesquipedalis (L.) Verdc. & $\mathrm{p}$ & 1 \\
\hline Pumpkins & Cucurbita spp. & $\mathrm{vc}$ & 1 \\
\hline Lettuce & Lactuca sativa $\mathrm{L}$. & $\mathrm{vc}$ & 1 \\
\hline Basil & Ocimum basilicum L. & $\mathrm{s}$ & 1 \\
\hline Pumpkin & Cucurbita moschata Duch. & $\mathrm{vc}$ & 1 \\
\hline Pea & Pisum sativum L. & $\mathrm{p}$ & 1 \\
\hline Sweet trefoil & Trigonella caerulea $\mathrm{L}$. & $\mathrm{s}$ & 1 \\
\hline Wheat & Triticum aestivum $\mathrm{L}$. & $\mathrm{c}$ & 1 \\
\hline Barley & Hordeum vulgare L. & $\mathrm{c}$ & 1 \\
\hline Cabbage & Brassica oleracea L. var. capitata L. & $\mathrm{vc}$ & 1 \\
\hline Maize & Zea mays L. & $\mathrm{c}$ & 1 \\
\hline Comfrey & Symphytum $\times$ uplandicum Nyman & $\mathrm{s}$ & 1 \\
\hline Radish & Raphanus sativus L. & $\mathrm{vc}$ & 1 \\
\hline St. John's wort & Hypericum perforatum $\mathrm{L}$. & $\mathrm{s}$ & 1 \\
\hline \multirow{4}{*}{ Total classes } & vc (vegetable crops) & & $31(58.5 \%)$ \\
\hline & s (spices) & & $11(20.8 \%)$ \\
\hline & $\mathrm{p}$ (pulses) & & $8(15 \%)$ \\
\hline & $\mathrm{c}$ (cereals) & & $3(5.7 \%)$ \\
\hline Total & & & 53 \\
\hline
\end{tabular}

All the collected accessions were grouped in classes (Table 2): vegetable crops (vc), pulses (p), cereals (c) and spices (s).

Vegetable crops (vc): garlic, pepper, tomato, cucumber, lettuce, onion, pumpkin, zucchini, cabbage and radish. Pulses (p): cowpea, common bean and peas. Cereals (c): wheat, barley and maize. Spices (s): horseradish, basil, parsley, opium poppy, blue fenugreek, comfrey and St. John's wort.

As expected, vc were the most collected, reaching a value of $58.5 \%$, s was $20.8 \%$ while $\mathrm{p}$ was $15.1 \%$ and $\mathrm{c}$ was $5.7 \%$ of the total.

Of all the collected accessions, tomato was the most frequent $(26.4 \%)$, followed by common bean $11.3 \%$ and onion (7.5\%).
Tomato (Solanum lycopersicum L.) was the most collected and had many different forms, characterised by different fruit shape, size and colour. Large size fruits are used for fresh consumption, especially as salad. It is the basis of many soups, and often, the tomato soup ("Ciorba de rosii") can have a variety of different starches added to it. Among tomatoes, the landrace "Inimă de Bou" is remarkable, a traditional variety the technique of cultivation of which was inherited from the great-grandparents.

Almost all collected pulses are represented by common bean accessions (75\%), the remaining part are yard-long bean and pea. Common bean seeds show great variation in colours (white, black and brown) and colour pattern and are grown mostly for 
dry bean production, but some types are used for green pod consumption. Accessions varied also in growth habit type: most of them are bush type others climbing on maize plants. Yard-long bean was found only in Peciu nou and farmers refer that the crop prefers sandy soils and seeds are sowed in mixtures (yellow and brown colours).

The third most collected species was onion (Allium сера L.) called "Сеарӑ" in the local language. It differs in many forms (semi-round to round), sizes (small to large) and colours (yellow to red). In Romania, there is a culture of onion production that dates back in time-valuable culinary vegetables and also has medicinal value, has been used for their medicinal properties for centuries. From Egypt (1600 BC), Allium cepa was introduced into the Mediterranean area and from there to all the Roman empire [43]. The most adopted form of cultivation is to transplant seedlings obtained by sowing their own seeds, passed down every year. The role in local cuisine and social life is very important: it is used in particular as salad and in countless dishes. However, today the traditional onion faces extinction due to the introduction of modern F1 hybrid seeds. Other causes of its extinction are: the agening of farmes-producers with no one to inherit their traditions, and a difficult business market affected by low import prices and problems in finding new commercial ways for this treasured vegetable.

Sweet peppers (Capsicum annuиm L.) "Ardei" in local name represented $66.7 \%$ of the total capsicum collected and had a widespread diffusion. The only accession of hot pepper (Capsicum spp.) was collected in Peciu nou. Fresh sweet fruits are used for traditional dishes called "Ardei umpluți”: stuffed with minced meat (usually pork), rice, onion and other vegetables and spices. The stuffed peppers are then baked in a rich, tomato based sauce. Fresh fruits are pickled in vinegar and oil and stored to be eaten throughout the year.

Among spices, the most collected was horseradish
(Armoracia rusticana G. Gaertn., B. Mey. \& Scherb.). In the local cuisine, grated root of the horseradish plant ("hrean") are mixed with vinegar and used as condiment of grilled meats and other traditional dishes. In Transylvania, red beet with horseradish is used as a salad served with lamb dishes at Easter called "sfecla cu hrean". The best remedy for backache are cataplasms of horseradish and it is one of the best Romanian folk cures for rheumatism (in 3-week treatment, the roots grated should be placed in a glass of warm milk to be drunk in the morning on an empty stomach), the slow digestion (a few teaspoons of grated horseradish during the meal), cold (horseradish is rich in vitamins, minerals, natural antibiotic substances, clear the nasal passages) and periodontitis (horseradish chewed long, flaky skin on the face tablets with horseradish syrup).

Although only one accession was collected, cabbage (Brassica oleracea L. var. capitata L.) in Romania is widespread and used in a many stuffed dishes, sour soup and stews servings. "Sarmale" are Romanian stuffed cabbage rolls traditionally served on Christmas and New Year's Eve, but also served throughout the year at weddings, baptism parties and other large celebrations. However, unfortunately, new cultivars are replacing the old landraces.

Also cucurbits (Cucurbita maxima Duch. ex Lam., Cucurbita moschata Duch. ex Lam. and Cucurbita реро L.) were widespread and four accessions were collected in Peciu Nou and Foeni. Great variation of fruit shape has been observed. Today, cucurbits are not very important crops and the most common types grown are that with large fruits-used as vegetables and as fodder for animals and others with smaller fruits ("zucchini"), used as vegetables.

Many different types of edible roots were available in almost every local market or grocery store. Most people have a general idea of what an edible root is, distinguished between true roots such as tuberous roots and taproots from non-roots such as tubers, rhizomes, corms and bulbs, and most have had at least 
a sampling of many types. The varieties found included horseradish (Armoracia rusticana G. Gaertn., B. Mey. \& Scherb.), parsley (Petroselinum crispum (Mill.) Fuss var. tuberosum (Bernh.) Mart. Crov.), radish (Raphanus sativus L.) and turnip (Brassica rapa L. em. Metzg.). Many were eaten right fresh from the ground while others taste best after they have been roasted or stewed.

Of particularly notes is the founding of opium poppy seeds (Papaver somniferum L.) with culinary uses: as whole seeds or as a paste of ground seeds. The seeds are used as a spice, a condiment, a decorative garnish, a thickener and a main ingredient. They are used in many baked goods, main course dishes and desserts.

In local markets, dried aerial parts of sweet trefoil (Trigonella caerulea L.) were found and sellers referred that this species is used as an aromatic for herbal tea and/or herbal infusion.

Farmers used to collect from ground cover or shady edge habitats plants of comfrey (Symphytum uplandicum Nyman) as a fodder plant and for edible uses.

Hypericum perforatum L. (St. John's wort) was referred as topical analgesic with therapeutic benefits for use in humans, equine, bovine, canine, feline, porcine or other animals (e.g. birds). Other referred uses are: for treatment, healing or relieving symptoms resulting from injured ligaments, tendons, muscles, bones, nerves, or for epidermal or dermal treatment or relief of conditions or symptoms caused by arthritis, neuralgia and pain.

\section{Discussion and Conclusions}

Genetic erosion was observed for grain field crops in the area. In fact, only one accession of wheat and one of barley were collected, while in the past (2000-2008), although in other Romanian regions, many landraces could still be found [16]. Triticum monococcum L., still cultivated few decades ago in Romania [44], could not be collected. But the search for this and other relict crops in Romania [45] will continue. In almost all selected towns, the species found during this collecting expedition were the same that had been reported from many collectors over many years. But, for many species, the number of accessions collected in this expedition was by far much lower. The timing of this expedition (autumn) and the careful identification of sites to explore within the territory of each town increased the collecting efficacy.

In the explored area, landrace preservation is associated to their cultural value, the geographical isolation of sites, the aesthetical and organoleptic preferences of the "farmers-maintainers". Important perspective for on farm conservation of landraces could be the promotion of their use in obtaining typical products or the attribution of European community marks [46, 47].

Finally, this collecting mission showed that in internal areas of Romania, germplasm of old landraces of many vegetable and crop species still survive. This preliminary mission indicated that it is urgent to continue the collecting in other agricultural districts of Romania.

\section{Acknowledgements}

This research was financially supported by Operative Program-European Regional Development Fund (OP ERDF) 2007-2013 Regione Basilicata; research project "Biodiversity of Species with High Nutraceutical and Agro-energetic Value" (AGRO.BIO.-Cod. 71/2012/21).

\section{References}

[1] Harris, D. 1996. The Origins and Spread of Agriculture and Pastoralism in Eurasia. London: Routledge.

[2] Damania, A., Valkoun, G. J., and Willcox, Qualset, C. 1998. The Origins of Agriculture and Crop Domestication. Aleppo Syria: ICARDA.

[3] Piperno, D., and Pearsall, D. 1998. The Origin of Agriculture in the Neotropics. San Diego: Academic Press.

[4] Gepts, P. 2006. "Plant Genetic Resources Conservation 
and Utilization: The Accomplishments and Future of a Societal Insurance Policy". Crop Science 46: 2278-2292. doi:10.2135/cropsci2006.03.0169.

[5] Hammer, K. 1984. "Das Domestications Syndrom (The Domestication Syndrome).” Die Kulturpflanze 32: 11-34.

[6] Hammer, K., Knüpffer, H., Laghetti, G., and Perrino, P. 1992. Seeds from the Past, a Catalogue of Crop Germplasm in South Italy and Sicily. Bari, Italy: Germplasm Institute of C.N.R..

[7] Harlan, J. R. 1972. "Genetics of Disaster." J. Environ. Qual. 1: 212-215.

[8] Frankel, O., and Bennett, E. 1970. Genetic Resources in Plants-Their Exploration and Conservation. Oxford: Blackwell Scientific Publications.

[9] Hawkes, J. G. 1971. "Conservation of Plant Genetic Resources.” Outlook Agric. 6: 248-253.

[10] Wilkes, G. 1977. "The World's Crop Plant Germplasm: An Endangered Resource.” Bull. At. Sci. 33: 8-16.

[11] Hammer, K., and Laghetti, G. 2005. "Genetic Erosion-Examples from Italy." Genetic Resources and Crop Evolution 52 (5): 629-634.

[12] Khoshbakht, K., and Hammer, K. 2010. Threatened Crop Species Diversity. Tehran: Shahid Beheshti Univ. Press.

[13] Vavilov, N. I. 1926. "Centers of Origin of Cultivated Plants." In Origin and Geography of Cultivated Plants, edited by Dorofeyev, V. F. Cambridge: Cambridge Univ. Press.

[14] Brush, S. B., and Stabinsky, D. 1996. Valuing Local Knowledge: Indigenous People and Intellectual Property Rights. Washington DC: Island Press.

[15] Brush, S. B. 2004. Farmers' Bounty. New Haven: Yale Univ. Press.

[16] Strajeru, S., Ibanescu, M., Costantinovici, D., Vatelainen, M., Negri, V., and Maxted, N. 2009. Landrace Inventory for Romania in European Landraces on Farm Conservation, Management and Use. Rome, Italy: Biodiversity International.

[17] Ibanescu, M., Strajeru, S., and Costantinovici, D. 2002. "Conservare in Situ a Biodiversity Agricole (in Situ Conservation of Agro-biodiversity)." Sanatatea Plantelor 10 (2): 137-142.

[18] Maxim, A., Rodica, S., FiŃiu, A., Sandor, M., Ruxandra, P., and Cristina, L. et al. 2007. "Preliminary Results Concerning the Preservation of Genetical Diversity of Different Vegetable Varieties at Usamv Cluj-napoca". Bulletin USAMV-CN, 63/2007.

[19] Velican, V. 1934. Experiences with Maize in Transylvania 1929-1932. Bucuresti: Analele I. C. A. R. Impr. Nat. Bucuresti.

[20] Cristea, M. 1975. Maize Germplasm. Bucuresti: Editura Ceres.

[21] Roman, L., Tataru, V., and Grecu, C. 1973. Improving the Biological Value of the Maize Land-Races through Sinthetic Populations. Dacia Cluj-Napoca: Contributii ale Cercet Arii Stiintifice la Dezvoltarea Agriculturii.

[22] Homorodeanu, S. 1974. "Local Maize Populations from Alba and Hunedoara Districts Cultivated under the Conditions of the Agricultural Experiment Station Geoagiu." Probl. Genet. Teor. Apl. 6: 214-237.

[23] Suba, T. 1973. "The Value of the Maize Populations from the Western Part of Romania in Respect of Initial Material for Breeding Work." Ph.D. dissertation, Inst. Agr. Timisoara.

[24] Grecu, C. 1962. Observations Regarding Some Land-Races of Maiz from Transylvania. Analele I. C. C. P. T. Fundulea, Set. C. 30.

[25] Cabulea, I., Roman, L., Tatarusi, V., and Grecu, C. 1975. "Local Maize Germplasm from Transylvania and Its Utilisation in Maize Breeding." Probl. Genet. Teor. Apl. 7: $57-90$.

[26] Ceapoiu, N., Eustatiu, N. N., Saulescu, Ittu, Gh., Giura, A., and Tapu, Z. 1975. "The Wheat Germplasm Collection of the Research Institute for Cereals and Industrial Crops Fundulea as a Source of Valuable Genes for Breeding." Probl. Genet. Teor. Apl. 7: 25-41.

[27] Draghici, L., Bude, A. L., and Tusa, C. 1975. "Utilization of the World Germplasm Sources in Barley Breeding." Probl. Genet. Teor. Apl. 7: 42-56.

[28] Vranceanu, A. V. 1974. Floarea Soarelui (Sunflower). Romania, Bucuresti: Acad. Ed..

[29] Szabó, A. T. 1981. "Problems of Genetic Erosion in Transylvania, Romania." Kulturpflanze 29: 47-62.

[30] Cociu, V. 1979. "Collection, Conservation and Utilization of Fruit Tree Germplasm in Romania." Probl. Genet. Teor. Apl. 9: 117-128.

[31] Popescu, G. H., Iacob, M., Badistean, M., Ionita, I., Stoian, M., and Petrescu, M. 1979. "Germplasm Reserves and Variability of Characteristics of the Varieties Preserved in Grape-Vine Collections in Romania." Probl. Genet. Teor. Apl. 11: 97-116.

[32] Enescu, V. 1979. "Present Problems of Forest Resources Conservation in Romania." Probl. Genet. Teor. Apl. 9: 129-136.

[33] Stanescu, V., Damian, J., Parascan, D., and Negrutiu, F. 1979. "Hardwood Genetic Sources in the Oriental Carpathians, Genetic-Evolutive Considerations." Probl. Genet. Teor. Apl. 9: 137-146.

[34] Cristea, M. 1981. Resurse Genetice Vegetale. Bucuresti: Acad. Ed..

[35] Romanian Statistical Yearbook. 2007. Statistical Yearbook. Bucarest: National Institute of Statistics Bucharest.

[36] Dodocioiu, A. M. R., and Mocanu, Dobre, M. 2012. "The Long Term Evolution of Phosphates from the Cambic 
Chernozem at ARDS Caracal Romania." Journal of Life Sciences 6: 557-562.

[37] Surd, V. 2010. "Restraints and Opportunities of the Romanian Rural Areas." Journal for Geography 5-1: 55-66.

[38] Stanila, A. L., Parichi, M., and Vartolomei, F. 2011. "Pedologycal Resources of Romania." Scientific LIV ISSN 1222-5339.

[39] Rusu, T., Moraru, P. I., Bogdan, I., Sopterean, M. L., and Pop, A. I. 2011. "Soil Temperature, Moisture Monitoring and Recommendations on the Optimum Sowing Period for the Main Crops in the Transylvanian Plain." Lucrări Ştiințifice-Seria Agronomie 54: 57-65.

[40] Szabó, A. T. 2013. "One Problem, two Questions, Three Books about the Vanishing Diversity of Cultivated Plants." Genet. Resour. Crop Evol. 60: 395-501.

[41] Missouri Botanical Garden. 2015. Tropicos.org. http://www.tropicos.org, accessed 10/01/2015.

[42] Toll, J. A. 1995. "Processing of Germplasm, Associated Material and Data." In Collecting Plant Genetic Diversity, edited by Guarino L., Ramanatha, V., and Rao Reid, R. Rome: CAB International for IPGRI.

[43] McCollum, G. D. 1976. "Onion and Allies, Allium (Liliaceae)." In Evolution of Crop Plants, edited by Simmonds, N. W. London: Longman.

[44] Pistrick, K. 1995. Maramures and Muntii Apuseni-Crop Plant Diversity and Living Past in Romania. Romania: Seed Saver Summer.

[45] Antonfie, M. M. 2011. The Red List of Crop Varieties for Romania. Sibiu, Romania: Lucian Blaga University.

[46] Montesano, V., Negro, D., Sarli, G., Logozzo, G., and Spagnoletti Zeuli, P. 2012. "Landraces in Inland Areas of the Basilicata Region, Italy: Monitoring and Perspectives for on Farm Conservation." Genet. Resour. Crop Evol. 59: 701-716.

[47] Spataro, G., and Negri, V. 2013. "The European Seed Legislation on Conservation Varieties: Focus, Implementation, Present and Future Impact on Landrace on Farm Conservation." Genet. Resour. Crop Evol. 60: 2421-2430. doi10.1007/s10722-013-0009-x. 